\title{
Value concept and economic growth model
}

\author{
Truong Hong Trinh a* $^{*}$ \\ a Department of Economics, The University of Danang, Vietnam \\ ${ }^{*}$ Corresponding author's e-mail: trinh.th@due.edu.vn
}

H I G H L I G H T S:

1. This paper explores the value concept and defines the utility function with incorporation of value and price.

2. The value added method is used for GDP measurement that explains the interrelationship between the expenditure approach and the income approach.

3. This paper provides a clear understanding on the GDP formula for measuring total production value in the economy.

4. This paper contributes a theoretical insight on economic growth to understand incentives and driving forces in economic growth model.

\begin{tabular}{ll} 
Article History & ABSTRACT \\
\hline $\begin{array}{l}\text { Received: } 15-10-2014 \\
\text { Revised Received: 26-10-2014 }\end{array}$ & $\begin{array}{l}\text { This paper approaches the value added method for Gross Domestic Product (GDP) } \\
\text { measurement that explains the interrelationship between the expenditure approach and the } \\
\text { income approach. The economic growth model is also proposed with three key elements of } \\
\text { Available online: } 02-12-2014\end{array}$ \\
$\begin{array}{l}\text { capital accumulation, technological innovation, and institutional reform. Although capital } \\
\text { accumulation and technological innovation are two integrated elements in driving economic } \\
\text { geywords: }\end{array}$ & $\begin{array}{l}\text { growth, institutional reforms play a key role in creating incentives that effect the } \\
\text { transitional and steady state growth rate in the real world economy. The paper provides a }\end{array}$ \\
Economic growth; & theoretical insight on economic growth to understand incentives and driving forces in \\
Institutional reform; & economic growth model. \\
Technological innovation. &
\end{tabular}

JEL Classification:

D24; D46; 047.

DOI: http://dx.doi.org/10.18533/jefs.v2i04.97

(C) 2014 The Authors. This is an open access article under the terms of the Creative Commons Attribution License 4.0, which allows use, distribution and reproduction in any medium, provided the original work is properly cited.

\subsection{Introduction}

The value concept has a very long history in economic and philosophical thought that attempt to explain two meanings of value: value-in-use and value-in-exchange. The difference between value-in-use (value) and value-inexchange (price) is the base of value theories that attempt to explain why goods and services are priced as they are how the value of goods and services come about. Neoclassical economists just only explain why goods and services are priced as they are, in which the price of goods and services is determined by the interaction of demand and supply. The explanation on the value of goods and services is still the big challenge.

In economics, the concepts of value, utility and price are important in the definition of value that has influence on how GDP is measured. There are two primary approaches for measuring GDP, which should yield the same result even though they measure completely different factors. The expenditure approach measures the total expenditures on the final commodities produced by a country in a given year. The income approach measures the total incomes earned by householders and firms in a country in a given year. However, there is still no a common formula on the 
interrelationship between the expenditure approach and the income approach. This results in a limited explanation on how GDP is measured, and which are driving factors in economic growth model.

From that reason, this paper explores the value concept and defines the utility function with incorporation of value and price. Based on the value concept, the value added method is used for GDP measurement. The GDP formula is very important to economic growth theories that identify driving forces in economic growth model. Exogenous growth theory attempts to explain economic growth by looking at capital accumulation (physical capital and human capital), endogenous growth theory holds that technological innovation (technological change and market demand) is significant contributions to economic growth. By synthesizing the literature, the economic growth model is proposed with three key elements of capital accumulation, technological innovation, and institutional reform. In addition, the paper emphases on the role of institutional reforms in creating incentives that affect the transitional and steady state growth rate.

\section{$2.0 \quad$ Value concept}

The value concept plays a crucial role in determining the relationship between demand and supply, and the total production value in the economy. A well-known neoclassical economist, Alfred Marshall (1890), defined value as the equilibrium price formed when the marginal cost equaled the marginal utility. The price consumers are willing to pay declines as the quantity purchased increases because of the diminishing returns obtained from additional purchases.

Most economists tried to make a clear distinction between value and price of a good or service. Baier (1969) offered a broader definition such as "value is the capacity of a good, service, or activity to satisfy a need or provide a benefit to a person or legal entity". Value is something which is perceived and evaluated at the time of consumption (Wikström, 1996; Woodruff and Gardial, 1996; Vargo and Lusch, 2004; Grönroos, 2008). There is a common understanding that value is created in the users' processes as value-in-use (Grönroos, 2011). In fact, value (value-in-use) is more appreciate guide to well-being than price (value-in-exchange). Moreover, the neoclassical utility concept is the same meaning as the contemporary value concept. Thus, the theory of value should be constructed upon a law of diminishing marginal value. The theory of value not only interprets relationship between value (value-in-use) and price (value-in-exchange), but also redefines the utility concept in this relationship as in Figure 01.

Figure 01: The value concept

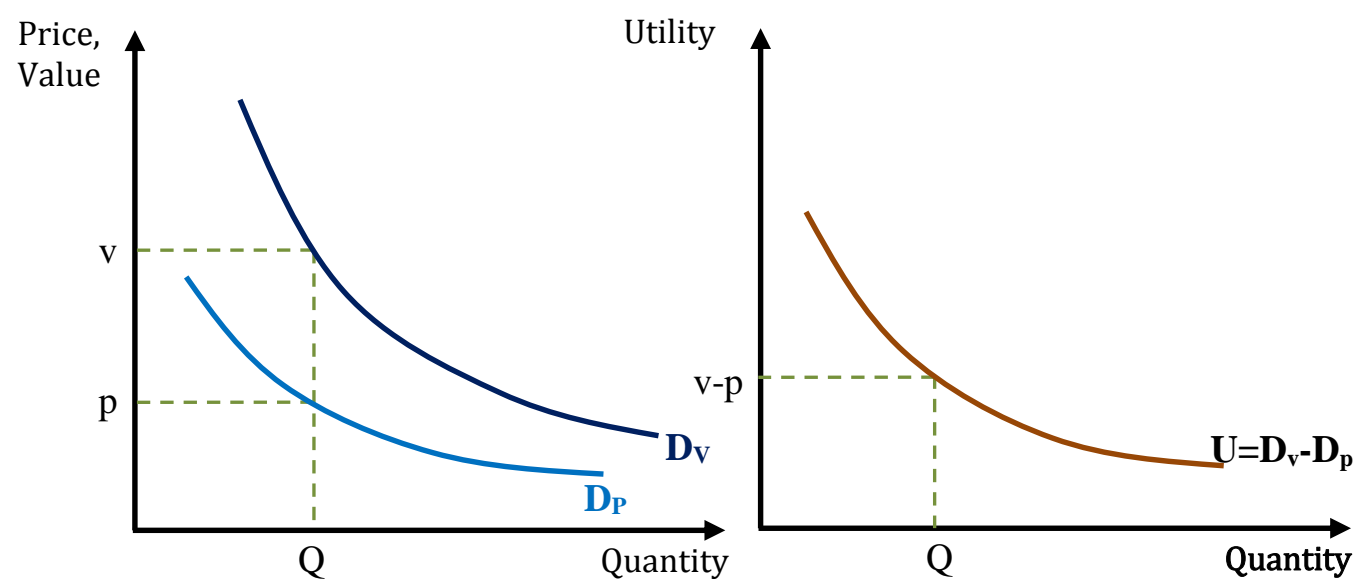

Based on the value concept, the utility function is defined with incorporation of value and price (Trinh et al., 2014a) as follows:

$T U=u \times Q=(v-p) \times Q=T V-T R$

Where, $V, p$, and $u$ are unit value, unit price, and unit utility, respectively. $T V, T R$, and $T U$ are total value, total revenue, and total utility, respectively.

Figure 02 presents the value creation perspective, in which the foundation of value creation is rapidly shifting from firm-centric view to customer experience, and joint value creation (Prahalad and Ramaswamy, 2004; 0jasalo, 2010; Trinh et al., 2014b). 


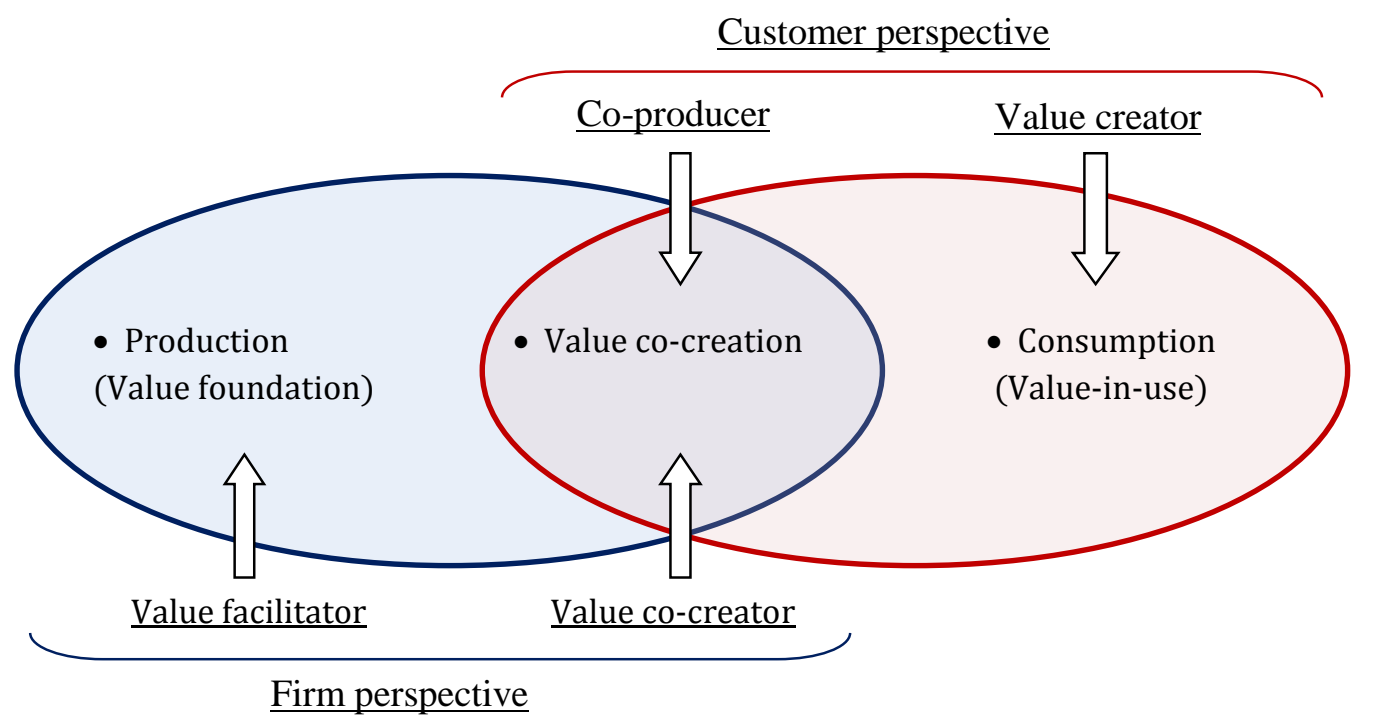

Source: Adapted from Grönroos and Voima (2012)

In firm perspective, the firm takes on the role of value facilitator, and also joins the customer's value creation as a value co-creator. Firm's production function is defined under the form of Cobb Douglas production function as follows:

$$
Q=f\left(K_{1}, L_{1}\right)=A_{1} \times K_{1}^{\alpha_{1}} \times L_{1}^{\beta_{1}}
$$

Where, $Q$ is total output of production. $A_{1}$ is firm's total factor productivity. $K_{1}$ and $L_{1}$ are firm capital and firm labour, respectively. $\alpha_{1}, \beta_{1}$, are the output elasticities of production input factors. By using the least-cost combination of production inputs, firm's cost function $\left(T C_{1}\right)$ can be determined as a function of output, depending on input prices and the parameters of the firm's production function as follows:

$$
T C_{1}=K_{1} \times w_{K_{1}}+L_{1} \times w_{L_{1}}
$$

Where, $T C_{1}$ is firm's total cost, $w_{K_{1}}$ and $w_{L_{1}}$ are unit costs of firm capital and firm labour. Moreover, firm's profit function is determined by the following formula.

$$
\Pi=T R-T C_{1}=p \times Q-K_{1} \times w_{K_{1}}-L_{1} \times w_{L_{1}}
$$

Where, $\Pi$ is firm profit and $T R$ is total revenue $(T R=p \times Q)$.

In customer perspective, the customer is always a value creator. The customer also takes part in the firm's production process as a co-producer. Since the value is created in the consumption process, customer capital $\left(K_{2}\right)$ and customer labour $\left(L_{2}\right)$ are added in the consumption function as follows:

$$
Q=f\left(K_{2}, L_{2}\right)=A_{2} \times K_{2}^{\alpha_{2}} \times L_{2}^{\beta_{2}}
$$

Where, $Q$ is total output of consumption. $A_{2}$ is customer's total factor productivity. $\alpha_{2}, \beta_{2}$, are the output elasticities of consumption input factors.

By using the least-cost combination of consumption inputs, customer's cost function ( $T C_{2}$ ) can be determined as a function of output, depending on input prices and the parameters of the customer's consumption function as follows:

$$
T C_{2}=K_{2} \times w_{K_{2}}+L_{2} \times w_{L_{2}}
$$

Where, $T C_{2}$ is customer's total cost, $w_{K_{2}}$ and $w_{L_{2}}$ are unit costs of customer capital and customer labour. Customer's utility function is determined by the following formula.

$$
U=T U-T C_{2}=(v-p) \times Q-K_{2} \times w_{K_{2}}-L_{2} \times w_{L_{2}}
$$


Where, $U$ is customer utility and $T U$ is total utility $(T U=u \times Q=(v-p) \times Q)$.

From the value creation perspective, value is created in the consumption process, both firm cost and customer cost have to consider in value creation. The joint cost function and the joint value function are determined as follows:

$$
\begin{aligned}
& T C=T C_{1}+T C_{2}=K_{1} \times w_{K_{1}}+L_{1} \times w_{L_{1}}+K_{2} \times w_{K_{2}}+L_{2} \times w_{L_{2}} \\
& V=\Pi+U=v \times Q-\left(K_{1} \times w_{K_{1}}+L_{1} \times w_{L_{1}}+K_{2} \times w_{K_{2}}+L_{2} \times w_{L_{2}}\right)=T V-T C
\end{aligned}
$$

Where, $V$ is joint value, $T V$ is total value $(T V=v \times Q)$ and $T C$ is total joint cost. $w_{K_{1}}$ and $w_{L_{1}}$ are unit costs of firm capital and firm labour. $w_{K_{2}}$ and $w_{L_{2}}$ are unit costs of customer capital and customer labour.

\subsection{GDP measurement}

Gross Domestic Product (GDP) is generally understood to present the health of a nation's economy. How is GDP measured? GDP is measured by valuating everything that is produced and adding all the value together. Figure 03 illustrates the approaches for measuring total production of an individual industry, in which total expenditure is equal to total income.

Figure 03: The GDP approaches

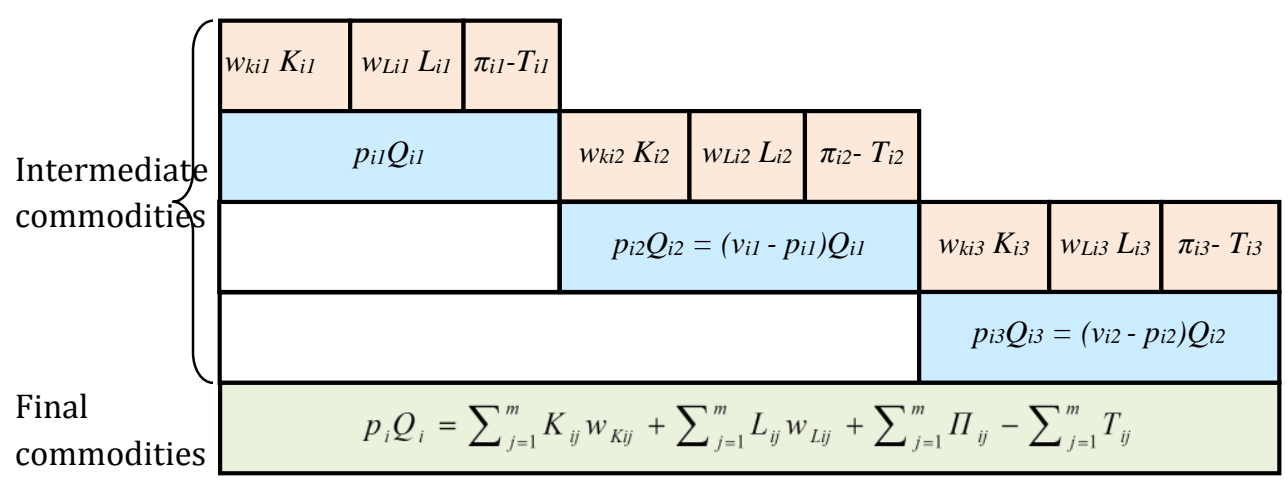

\subsection{The production approach}

The production (value added) approach measures GDP by summing up production value added $\left(p_{i} Q_{i}\right)$ of industries in the economy. The value added method determines production value added $\left(p_{i j} Q_{i j}\right)$ in the industry $i$ through exchange processes between the firm and the customer. For the intermediate exchanges, intermediate firms play dual roles of the firm and the customer. In the initial exchange process, firms provide the commodities to customers. Firm profit $\left(\Pi_{i 1}\right)$ and customer utility $\left(U_{i 1}\right)$ are determined as follows:

$$
\begin{aligned}
& \Pi_{i 1}=p_{i 1} \times Q_{i 1}-K_{i 1} \times w_{K_{i 1}}-L_{i 1} \times w_{L_{i 1}}-T_{i 1} \\
& U_{i 1}=\left(v_{i 1}-p_{i 1}\right) \times Q_{i 1}-K_{i 2} \times w_{K_{i 2}}-L_{i 2} \times w_{L_{i 2}}-T_{i 2}
\end{aligned}
$$

Where $T_{i 1}$ is are tax and subside of the firm and $T_{i 2}$ is tax and subside of the customer. Customer then plays a role of the firm in the next exchange process. The customer utility $\left(U_{i 1}\right)$ in the initial exchange process is also the firm profit $\left(\Pi_{i 2}\right)$ in the next exchange process.

$$
\begin{aligned}
& \Pi_{i 2}=p_{i 2} \times Q_{i 2}-K_{i 2} \times w_{K_{i 2}}-L_{i 2} \times w_{L_{i 2}}-T_{i 2} \\
& U_{i 2}=\left(v_{i 2}-p_{i 2}\right) \times Q_{i 2}-K_{i 3} \times w_{K_{i 3}}-L_{i 3} \times w_{L_{i 3}}-T_{i 3}
\end{aligned}
$$

For the final exchange process, customers are also final consumers that buy the final commodities from the last firms in the exchange processes. Firm profit $\left(\Pi_{i m}\right)$ is given as follows: 


$$
\Pi_{i m}=p_{i m} \times Q_{i m}-K_{i m} \times w_{K_{i n}}-L_{i m} \times w_{L_{i m}}-T_{i m}
$$

Total joint value (value added) of industry $i$ is determined by the following formula.

$$
\sum_{j=1}^{m} \Pi_{i j}=\sum_{j=1}^{m} p_{i j} \times Q_{i j}-\sum_{j=1}^{m} K_{i j} \times w_{K_{i j}}-\sum_{j=1}^{m} L_{i j} \times w_{L_{i j}}-\sum_{j=1}^{m} T_{i j}
$$

From above formula, total production value of industry $i\left(p_{i} \times Q_{i}+I_{i}=\sum_{j=1}^{m} p_{i j} \times Q_{i j}+\sum_{j=1}^{m} I_{i j}\right)$ is defined as a sum of production value of intermediate firms, in which total expenditure $\left(\sum_{j=1}^{m} p_{i j} \times Q_{i j}+\sum_{j=1}^{m} I_{i j}\right)$ is equal to total income $\left(\sum_{j=1}^{m} K_{i j} \times w_{K_{i j}}+\sum_{j=1}^{m} L_{i j} \times w_{L_{i j}}+\sum_{j=1}^{m} \Pi_{i j}+\sum_{j=1}^{m} T_{i j}+\sum_{j=1}^{m} I_{i j}\right)$, in which $\sum_{j=1}^{m} I_{i j}$ is capital investment of industry $i$. By setting $K_{i} \times w_{K i}=\sum_{j=1}^{m} K_{i j} \times w_{K_{i j}}, L_{i} \times w_{L i}=\sum_{j=1}^{m} L_{i j} \times w_{L_{i j}}, \Pi_{i}=\sum_{j=1}^{m} \Pi_{i j}, T_{i}=\sum_{j=1}^{m} T_{i j}, I_{i}=\sum_{j=1}^{m} I_{i j}$, total production value of industry $i$ can be expressed as follows:

$$
p_{i} Q_{i}+I_{i}=K_{i} \times w_{K_{i}}+L_{i} \times w_{L_{i}}+\Pi_{i}+T_{i}+I_{i}
$$

Total production value (GDP) of the economy with $n$ industries is determined as follows:

$$
\begin{aligned}
& G D P=\sum_{i=1}^{n} p_{i} \times Q_{i}+\sum_{i=1}^{n} I_{i} \\
& G D P=\sum_{i=1}^{n} K_{i} \times w_{K_{i}}+\sum_{i=1}^{n} L_{i} \times w_{L_{i}}+\sum_{i=1}^{n} \Pi_{i}+\sum_{i=1}^{n} T_{i}+\sum_{i=1}^{n} I_{i}
\end{aligned}
$$

By setting $\sum_{i=1}^{n} S_{F i}=\sum_{i=1}^{n} \Pi_{i}+\sum_{i=1}^{n} I_{i}-\sum_{i=1}^{n} D_{i}$, in which $\sum_{i=1}^{n} S_{F i}$ is firm savings and $\sum_{i=1}^{n} D_{i}$ is capital depreciation. Thus, GDP from Equation (18) can be rewritten as follows:

$$
G D P=\sum_{i=1}^{n} K_{i} \times w_{K_{i}}+\sum_{i=1}^{n} L_{i} \times w_{L_{i}}+\sum_{i=1}^{n} S_{F i}+\sum_{i=1}^{n} D_{i}+\sum_{i=1}^{n} T_{i}
$$

From Equation (17), setting $P Q=\sum_{i=1}^{n} p_{i} \times Q_{i}$ and $I=\sum_{i=1}^{n} I_{i}$, in which total expenditure on final commodities $(P Q)$ includes personal expenditure $(C)$, government expenditure $(G)$, and net export $(N X)$. GDP measurement under the expenditure approach can be expressed as follows:

$G D P=C+G+I+N X$

From Equation (19), setting $L W_{L}=\sum_{i=1}^{n} L_{i} \times w_{L i}, K W_{K}=\sum_{i=1}^{n} K_{i} \times w_{K i}, S_{F}=\sum_{i=1}^{n} S_{F i}, D=\sum_{i=1}^{n} D_{i}$, and $T=\sum_{i=1}^{n} T_{i}$, GDP measurement under the income approach can be expressed as follows:

$$
G D P=K W_{K}+L W_{L}+S_{F}+D+T
$$

GDP is measured through total income that includes capital interest $\left(K W_{K}\right)$, labor wage $\left(L W_{L}\right)$, firm savings $\left(S_{F}\right)$, capital depreciation $(D)$, tax and subside $(T)$.

\subsection{The expenditure approach}

The expenditure approach measure GDP by using data on personal expenditure, capital investment, government expenditure, and net export. GDP using in the expenditure approach is the sum of personal expenditure $(C)$, capital investment $(I)$, government expenditure $(G)$, and net export $(N X)$.

$G D P=C+I+G+N X$ 
Table 01 shows the hypothetical data for the expenditure approach. The economy produces 100 units of commodity with unit price of 10, in which personal expenditure is 70 units, government expenditure is 20 units, net export is 10 units in which export is 20 units and import is 10 units. Capital investment is 250.

\begin{tabular}{lcccc}
\hline \multicolumn{5}{c}{ Table 01: The expenditure approach for GDP measurement } \\
\hline Items & Symbol & Quantity & Price & Amount \\
\hline Personal expenditure & C & 70 & 10 & 700 \\
Capital investment & I & - & - & 250 \\
Government expenditure & G & 20 & 10 & 200 \\
Net export & NX & 10 & 10 & 100 \\
\hline Gross Domestic Product & GDP & & & 1250 \\
\hline
\end{tabular}

$G D P=C+I+G+N X=700+250+200+100=1250$

\subsection{The income approach}

The income approach measures GDP by summing up the incomes that firms pay households for the resources they hire such as labor wage $\left(L W_{L}\right)$, capital interest $\left(K W_{K}\right)$, firm saving $\left(S_{F}\right)$, capital depreciation $(D)$, tax and subside $(T)$. GDP using the income approach is the sum of personal expenditure $(C)$, capital depreciation $(D)$, total saving (S), tax and subside $(T)$.

$$
G D P=C+D+S+T
$$

Table 02 shows the hypothetical data for the income approach. The economy uses 100 units of capital with interest rate of 5, 100 units of labor with wage rate of 3 , tax and subside are 50. Total saving $(S)$ is a sum of household saving $\left(S_{C}\right)$ and firm saving $\left(S_{F}\right)$ as follows:

$$
\begin{aligned}
& S_{C}=K W_{K}+L W_{L}-Q_{C} \times p=500+300-700=100 \\
& S_{F}=\Pi+I-D \\
& \Pi=p \times Q-K W_{K}-L W_{L}-T=1000-500-300-50=150 \\
& \Rightarrow S_{F}=150+250-200=200 \\
& S=S_{C}+S_{F}=100+200=300
\end{aligned}
$$

\begin{tabular}{|c|c|c|c|c|}
\hline \multicolumn{5}{|c|}{ Table 02: The income approach for GDP measurement } \\
\hline Items & Symbol & Quantity & Price & Amount \\
\hline Capital interest & $\mathrm{KW}_{\mathrm{K}}$ & 100 & 5 & 500 \\
\hline Labor wage & $\mathrm{LW}_{\mathrm{L}}$ & 100 & 3 & 300 \\
\hline Firm saving & $\mathrm{SF}_{\mathrm{F}}$ & - & - & 200 \\
\hline Capital depreciation & D & - & - & 200 \\
\hline Tax and subside & $\mathrm{T}$ & - & - & 50 \\
\hline Gross Domestic Product & GDP & & & 1250 \\
\hline
\end{tabular}

$$
G D P=C+D+S+T=700+200+300+50=1250
$$

Figure 04 illustrates the circular flow of income and expenditure. Households receive capital interest $\left(K W_{K}=500\right)$ and labor wage $\left(L W_{L}=300\right)$ from the resource market, and make personal expenditure $(C=700)$ in the commodity market. Firms make capital investment $(I=250)$ and get capital depreciation $(D=200)$, government purchases commodities $(G=200)$, and the rest of the world purchases net export $(N X=100)$. Total saving $(S=300)$ includes household saving $\left(S_{C}=100\right)$ and firm saving $\left(S_{F}=200\right)$. Household saving $\left(S_{C}=100\right)$ and firm profit $(\Pi=150)$ would lend in the financial market, where government and the rest of the world would borrow to finance their deficits. 


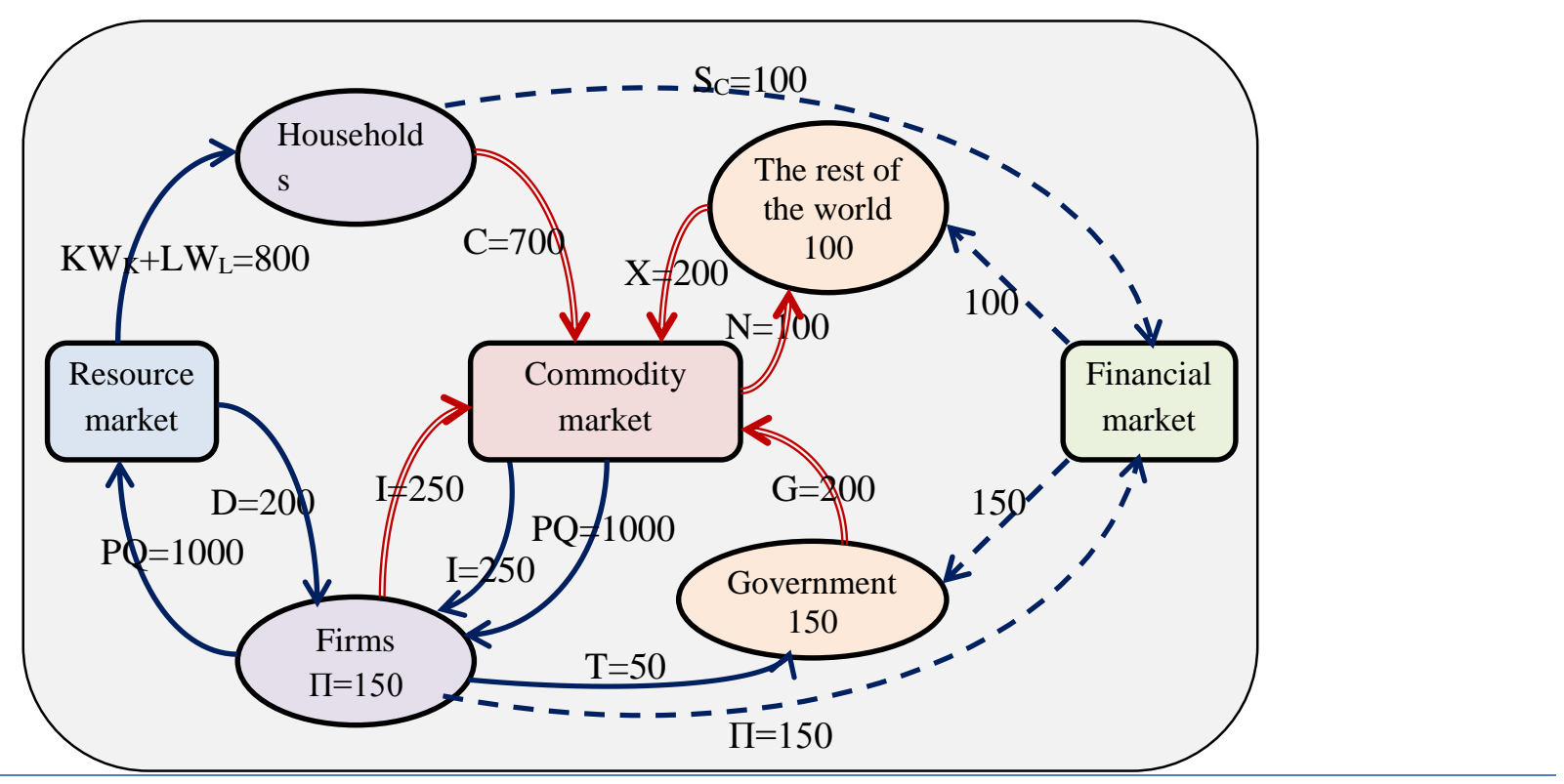

\subsection{Economic growth model}

From the GDP formula, there are two ways of increasing GDP of the economy: capital accumulation and technological innovation. Capital accumulation increases the number of inputs with the old way that go into the production process. Technological innovation is the new ways that get more output from the same number of inputs. Based on this, there are two economic growth theories.

\subsection{Exogenous growth theory}

Exogenous growth theory attempts to explain economic growth by looking at capital accumulation (physical capital and human capital), technological innovation (technological change and market demand) is assumed exogenous. Therefore, the growth rate of the economy converges to the steady state that is determined by the rate of capital accumulation. The differences in GDP per capita depending on the paths of capital accumulation through saving rates (Solow, 1956), preference (Cass, 1965; Koopmans, 1965) or other exogenous parameters.

According to the exogenous growth model, if all economies have the same taste and technology parameters, and the same population growth rate, then they should have the same steady state level of GDP per capita. The rate of economic growth depends on the capital accumulation, the countries with the low capital accumulation grows more rapidly than those with higher capital accumulation. In addition, countries with low GDP per capita grow more rapidly than those in which beginning GDP per capita are high. Although the model states "conditional convergence" with unrealistic assumptions of the same population growth and technology progress in various countries. The exogenous growth model provides a theoretical base for general equilibrium analysis, the basis for much of today's economic theory (McCallum, 1996).

In response to the various failures of the exogenous model, Romer (1986) and Lucas (1988) have developed endogenous growth models in which steady state growth can be generated endogenously. Romer (1990), Grossman and Helpman (1991), and Aghion and Howitt (1992) stated that technological change is endogenous that is driven by $\mathrm{R} \& \mathrm{D}$ and innovations.

\subsection{Endogenous growth theory}

Endogenous growth theory holds that investment in human capital, innovation and knowledge are significant contributions to economic growth. The role of human capital in economic growth has been extensively analyzed in the theoretical literature (Nelson and Phelps, 1966; Welch, 1970; Lucas, 1988; Romer, 1990). According to Freire-Seren (2001), human capital contributes to growth under two identified ways: First, human capital can directly participate in production as a productive factor. The quantity of human capital would directly generate the growth of output. This effect is so called level effect. Second, the quality of human capital can contribute to raising the innovation diffusion and adoption of new technologies that affect productivity growth. This second effect is so called rate effect. In addition, investment in innovation and knowledge will translate into new technologies as well as efficient ways in using the physical capital and the human capital. Romer (1986) and Lucas (1988) emphasized on the importance of 
externalities in the accumulation of knowledge and human capital in offsetting the decreasing returns to scale in capital accumulation.

Figure 05: Driving forces of economic growth

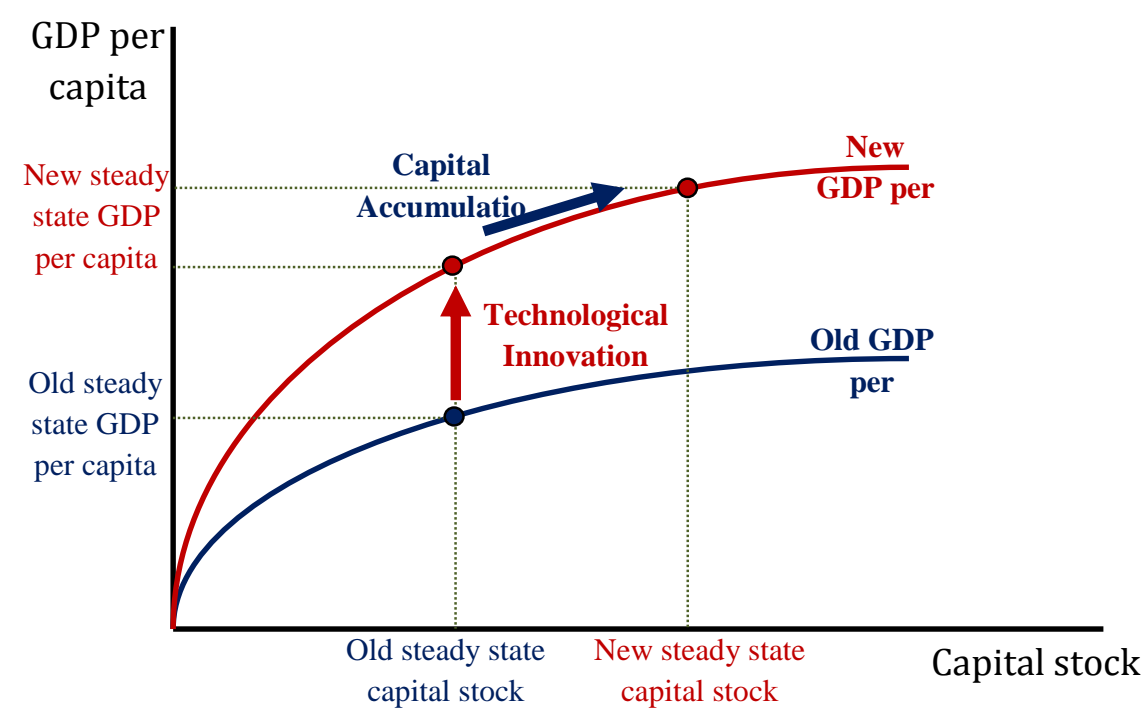

The rate of capital accumulation is one of the main factors determining the level of GDP per capita. Although its effects could be more or less permanent depending on the extent to which technological innovation is embodied in new capital investment. The rate of economic growth depends on two factors of capital accumulation (quantity of capital stock) and technological innovation (quality of capital stock) as in Figure 05. A country with the same capital stock but better technological innovation (a higher steady state rate) will grow faster than another country. This is due to the greater distance form steady state levels. Similarly, a country with a lower initial capital stock than another country, but the same technological innovation will grow faster because of the wider gap to be closed.

In these models, institutions have well-defined property rights and market structures. The difference in GDP per capita and growth rate are not explained by variation in institutions. A economic growth model that ignores the role of institutions may oversimplify the analysis and the important linkages in the dynamics of economic growth (Tebaldi and Elmslie, 2008).

\subsection{Institutions and economic growth}

Capital accumulation and technological innovation are two integrated elements in driving economic growth. On the one hand, physical capital and human capital are essential forces in applying new technology and expanding market demand. On the other hand, technological innovation creates new economic opportunities for investment in physical capital and human capital. However, capital accumulation and technological innovation must be organized to produce valuable commodities in the economy. The key to producing and organizing the factors of production are institutions that create appropriate incentives for economic growth as in Figure 06.

Figure 06: Incentives for economic growth

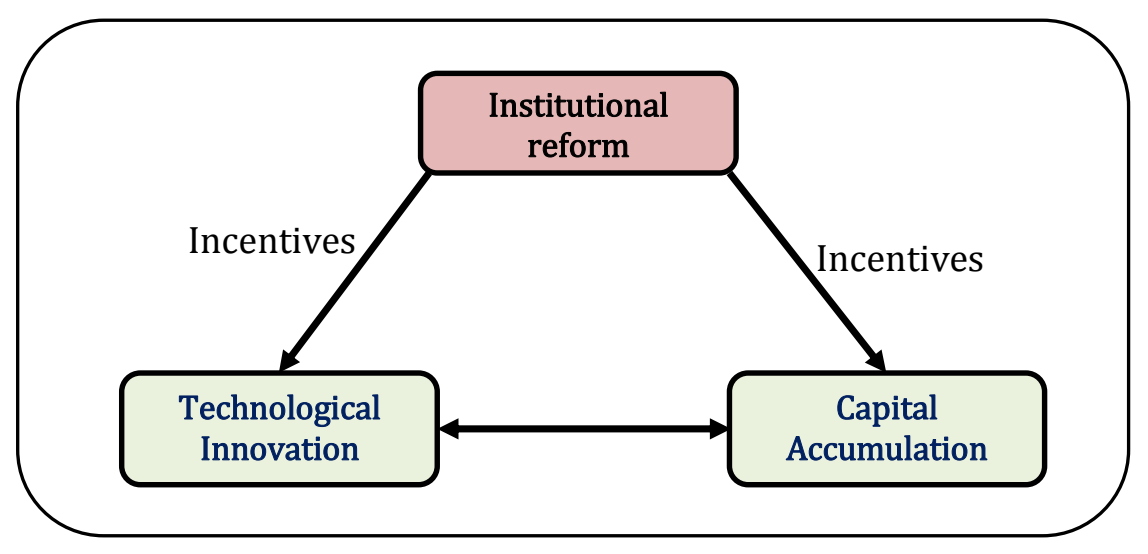


The role of institutions has become one of the most popular research areas in development economics over the last twenty years (North, 1990; Huang and Xu, 1999; Rodrik et al., 2004; Acemoglu et al., 2005; Acemoglu and Robinson, 2010). What are institutions exactly? North (1990) defined institutions as the "rules of the game" that shape human interaction and structure economic incentives within a society. The key institutions are property rights, honest government, political stability, and dependable legal system, competitive and open markets that have been very positive for both innovation and economic growth (Cowen and Tabarrok, 2011).

Institutional reform derived from political power that effect the choice of economic institutions and the future evolution of political institutions, in which the political power comes from two sources of de jure political power and de facto political power (Acemoglu et al., 2005). The de jure political power refers to power that originates from the political institutions. The de facto political power depends on economic ability of a group to use existing political institutions to hire or use force against different groups even if they are not allocated power by political institutions. Although, the political institutions change relatively slowly, they play an important role in determining economic institutions (Acemoglu and Robinson, 2010). The economic institutions shape the incentives of key economic actors in society that have influence on capital accumulation and technological innovation. The differences in economic institutions are the fundamental cause of different patterns of economic growth, in which growth miracles are possible but so are growth disasters (Maddison, 2007).

\subsection{Conclusions}

The value concept plays a crucial role in determining relationship between demand and supply, and the total production value in the economy. Since the neoclassical utility concept is the same as contemporary value concept and value-in-use (value) is more appreciate guide to well-being than value-in-exchange (price), should economists use the law of diminishing marginal utility to explain on the demand. The fact is that the theory of value must construct upon a law of diminishing marginal value. Based on the value concept, the utility function is defined with incorporation of value and price. Since value is created in the consumption process, both firm cost and customer cost have to consider in value creation. The value added method is then used for GDP measurement by summing up production value added of industries in the economy. The GDP formula not only explains the interrelationship between the expenditure approach and the income approach, but also presents driving factors on economic growth.

The paper provides the clear understanding on theoretical GDP formula for measuring total production value in the economy. National accounting process takes into account the national income and economic accounts. In practice, the expenditure approach and the income approach with different data sources are used to measure GDP. The small statistical discrepancy is adjusted to make total expenditure equal total income. In addition, the paper contributes the theoretical insight on economic growth to understand incentives and driving forces in economic growth model. The developing countries can catch up with the developed countries through capital accumulation and technological innovation, but the fact that some countries have faster growth rates than other countries, in which institutional reform plays an important role in creating initiatives that affect the transitional and steady state growth rate in the real world economy.

\section{Acknowledgements}

The author is grateful to anonymous reviewers for valuable comments which helped improve the overall contents and presentation of the paper considerably.

\section{References}

Acemoglu, D., Johnson, S. and Robinson, J. A., 2005. Institutions as the fundamental cause of long-run growth. Handbook of Economic Growth, P. Aghion and S. N. Durlauf, eds., Elsevier, 385-482.

Acemoglu, D. and Robinson, J. A., 2010. The role of institutions in growth and development. Review of Economics and Institutions, 1(2): 1-33.

Aghion, P. and Howitt, P., 1992. A model of growth through creative destruction. Econometrica, 60(2): 323-351.

Baier, K., 1969. What is value? An analysis of the concept. Value and the Future: The Impact of Technology change on American Values, K. Baier and N. Rescher, eds., New Yord: The Free Express, 33-67.

Cass, D., 1965. Optimum Growth in an Aggregative Model of Capital Accumulation. Review of Economic Studies, 32: 233-240.

Cowen, T. and Tabarrok, A., 2011. Modern Principles of Economics. Worth Publishers.

Freire-Seren , M. J., 2001. Human capital accumulation and economic growth. Investigaciones Economicas, 25(3): 585602.

Grönroos, C., 2011. A service perspective on business relationships: The value creation, interaction and marketing 
interface. Industrial marketing Management, 40(2): 240-247.

Grossman, G. M. and Helpman, E., 1991. Innovation and Growth in the Global Economy. MIT Press, Cambrige M.A. and London.

Grönroos, C., 2008. Service logic revisited: who creates value? And who co-creates? European Business Review, 20(4): 298-314.

Grönroos, C. and Voima, P., 2012. Making sense of value and value co-creation in service logic. Hanken School of Economics: Helsinki, Finland.

Huang, H. and Xu, C., 1999. Institutions, Innovations and Growth. American Economic Review, 89(2): $438-443$.

Koopmans, T. C., 1965. On the Concept of Optimal Economic Growth. in Study Week on the Econometric Approach to Development Planning, North-Holland Pub. Co.

Lucas, R. E., 1988. On the Mechanics of Economic Development. Journal of Monetary Economics, 22(1): 3-42.

Maddison, A., 2007. Contours of the World Economy 1-2030 AD: Essays in Macro-Economic History. Oxford University Press.

Marshall, A., 1890. Principles of Economics. London: Macmillan.

McCallum, B. T., 1996. Neoclassical vs. Endogenous Growth Analysis: An Overview. Economic Quarterly, Federal Reserve Bank of Richmond, 82(4): 41-71.

Nelson, R. and Phelps, E., 1966. Investment in humans, technological diffusion, and economic growth. American Economic Review, 56: 69-75.

North, D. C., 1990. Institutional Change, and Economic Performance. Cambridge University Press, New York.

Ojasalo, K., 2010. The shift from co-production in services to value co-creation. The Business Review, Cambridge, 16(1): 171-177.

Prahalad, C. K. and Ramaswamy, V., 2004. Co-creation experiences: The next practice in value creation. Journal of Interactive Marketing, 18(3): 5-14.

Rodrik, D., Subramanian, A. and Trebbi, F., 2004. Institutions rule: The Primacy of Institutions Over Geography and Integration in Economic Development. Journal of Economic Growth, 9(2): 131-165.

Romer, P. M., 1986. Increasing Returns and Long-Run Growth. Journal of Political Economy, 94: 1002-1037.

Romer, P. M., 1990. Endogenous Technological Change. Journal of Political Economy, 98: 71-102.

Solow, R. M., 1956. A Contribution to the Theory of Economic Growth. The Quarterly Journal of Economics, 70(1): 6594.

Tebaldi, E. and Elmslie, B., 2008. Institutions, Innovation and Economic Growth. Journal of Economic Development, 33(2): 27-53.

Trinh, T. H., Kachitvichyanukul, V. and Khang, D. B., 2014a. The co-production approach to service: a theoretical background. Journal of the Operational Research Society 65(2): 161-168.

Trinh, T. H., Liem, N. T. and Kachitvichyanukul, V., 2014b. A game theory approach for value co-creation systems. Production \& Manufacturing Research, 2(1): 253-265.

Vargo, S. L. and Lusch, R. F., 2004. Evolving to a new dominant logic for marketing. Journal of Marketing, 68(1): 1-17.

Welch, F., 1970. Education in Production. Journal of Political Economy, 78(1): 35-59.

Wikström, S., 1996. The customer as co-producer. European Journal of Marketing, 30(4): 6-19.

Woodruff, R. B. and Gardial, S. (1996). Know Your Customers: New Approaches to Understanding Customer Value and Satisfaction. Blackwell Business, Cambridge, MA. 